\title{
PREVALENCE OF ASTHMA, RHINITIS AND ECZEMA IN 6 - 7 YEARS OLD STUDENTS FROM THE WESTERN DISTRICTS OF SÃO PAULO CITY, USING THE STANDARDIZED QUESTIONNAIRE OF THE "INTERNATIONAL STUDY OF ASTHMA AND ALLERGIES IN CHILDHOOD” (ISAAC)-PHASE IIIB
}

Renata Gontijo Lima, AC. Pastorino, RRD Casagrande, D Sole, C Leone, CMA Jacob

\footnotetext{
Lima RG, Pastorino AC, Casagrande RRD, Sole D, Leone C, Jacob CMA. Prevalence of asthma, rhinitis and eczema in 6 - 7 years old students from the western districts of São Paulo City, using the standardized questionnaire of the "International Study of Asthma and Allergies in Childhood" (ISAAC)-Phase IIIB. Clinics. 2007,62(3):225-34.
}

The aims of the present work were the evaluation of allergic disease prevalence among 6 and 7 year-old students from the western districts of São Paulo city and the comparison of these data with those obtained in the International Study of Asthma and Allergies in Childhood (ISAAC) phase I, performed in the central-southern districts of São Paulo, using the ISAAC standardized written questionnaire.

METHODS: 5,040 questionnaires were distributed and 3,312 were returned. Proportional differences were estimated by Chi square or Fisher exact tests. Odds Ratio and 95\% confidence intervals between genders and allergic diseases were calculated. Values of $p<0.05$ were considered statistically significant.

RESULTS: The corrected prevalences found were: asthma 24.4\%, medical diagnosis of asthma 5.7\%, rhinitis $25.7 \%$, rhinoconjunctivitis $11.3 \%$, medical diagnosis of rhinitis $20.0 \%$, atopic eczema $9.2 \%$. Significant associations between asthma and rhinitis $(\mathrm{OR}=3.3)$, asthma and eczema $(\mathrm{OR}=2.2)$, and rhinitis and eczema $(\mathrm{OR}=2.8)$ occurred. The male gender was prevalent regarding asthma and rhinitis. Compared to data from ISAAC phase I, higher asthma prevalence and severity, and lower values for rhinitis and eczema were observed in this study.

CONCLUSIONS: The present study evidenced high prevalences for asthma and rhinitis compared to the children's medical diagnosis. The male gender predominated in all positive responses regarding asthma and rhinitis. The most frequent associations observed were between asthma and rhinitis and asthma and eczema. In the western districts of São Paulo, a higher prevalence of asthma symptoms and severity and lower prevalences for rhinitis and eczema occurred compared to the central-southern districts of the city.

KEY WORDS: Asthma, Rhinitis, Eczema, Prevalence, Children

\section{INTRODUCTION}

In recent decades, the prevalence of allergic diseases has increased worldwide, especially in western countries, affect-

Children's Institute, Institute, Hospital das Clinicas, Faculty of Medicine, University of Sao Paulo, Sao Paulo, SP, Brazil.

Email: renata-gontijo@uol.com.br

Received for publication on September 09, 2006.

Accepted for publication on December 17, 2006. ing around $30 \%$ of the population ${ }^{1,2}$. Stabilization has been observed in relation to asthma, while rhinitis and atopic eczema continue to increase in several regions of the world, although the number of studies regarding atopic eczema is lower, due to the difficulties related to its diagnosis ${ }^{2-4}$.

Oscillations in the prevalence of allergic disease have been attributed to changes in environmental conditions, such as greater exposure to aeroallergens, dietary changes and improved hygiene conditions with lower exposure to 
infectious agents. Clear differences in allergy prevalences between western vs. oriental cultures and urban vs. rural populations have been detected, possibly resulting from differences in the same factors reported above $e^{5,6}$.

The variety of methods used in epidemiological studies of these diseases makes direct comparisons between their results difficult. In the last few decades, the instruments most used to enable the investigation of population samples were written questionnaires (WQs), both those applied by trained interviewers and those which are self-applied. Such procedures, when standardized and validated locally, facilitate temporal and regional comparison of the clinical and epidemiological data obtained $^{7-9}$.

The ISAAC project was elaborated with the objective of standardizing an investigation method for allergic disease epidemiology in the pediatric age group, which permitted the acquisition of data regarding asthma, rhinitis and atopic eczema in several countries. In 1995, Solé et al. applied the ISAAC questionnaire to 6 and 7 year-old students of the central-southern districts of São Paulo City and detected a prevalence for sibilus of $21.3 \%$, nasal symptoms of $33.8 \%$ and eczema of $10.6 \%$ in the preceding 12 months ${ }^{10-14}$.

São Paulo City presents different climatic and topographic variations and the current study, named ISAAC West phase IIIB, aimed to determine allergic disease prevalences in the western districts of the City of São Paulo and compare these data with those of phase I performed in the central-southern districts of the city within the same age group.

\section{CAUISTICS AND METHODS}

The municipality of São Paulo is considered the third largest urban conglomerate in the world; its western region, where this study was concentrated, is considered one of the most polluted regions of the city. In relation to demographic factors, the districts included in this study correspond to $5.4 \%$ of the total population of São Paulo and present high demographic densities, including favelas, with predominantly low incomes ${ }^{15-17}$. Thirty-five exclusively municipal public schools distributed throughout this district were included in the study; its population presents precarious living conditions.

The method used was the standardized ISAAC questionnaire, which is presented in three modules: the first includes eight questions related to asthma; the second includes six questions related to rhinitis and the last includes seven questions related to atopic eczema. The first two questions in each module discuss symptom preva- lence, both at any time during the child's life and in the preceding 12 months, which diminishes the possibility of recollection errors and provides greater specificity to the question in order to determine allergic disease prevalence. Question number six regarding asthma and rhinitis and number seven regarding eczema aim to evaluate prior medical diagnoses. Some questions are used to evaluate symptom severity, such as those which evaluate the presence of speech limitations due to asthma symptoms, compromise of the child's activities due to rhinitis symptoms and sleep alterations due to pruritis in cases of eczema. Determination of the months of the year in which nasal symptoms occur characterizes the symptoms of persistent or seasonal rhinitis, while question number three, which associates nasal and ocular symptoms (“..., has this nose problem been accompanied by itchy-watery eyes?") relates these symptoms with atopy. In relation to the eczema module, it worth highlighting that questions \#3 and \#4 are considered the most specific for evaluating the presence of symptoms in locations typical of eczema and the child's age at the onset of symptoms ${ }^{13,14}$.

A total of 5,040 written questionnaires were handed out, which, after being filled out by the parents or guardians, were collected during the months of June to October, 2002, with a devolution rate of $65.7 \%$. Thus, 3,312 students were included in the final analysis. The data obtained through the WQs was typed in duplicate, according to the requirements of the ISAAC central committee, using the Epi-Info program version 6.0, sent to the participating research centers. In virtue of the devolution rate obtained, consideration was given to observing the prevalence of each ISAAC WQ question in a group of students whose questionnaires were not returned, with posterior comparison of these values with those obtained from the final sample of returned WQs. A probabilistic random sample of 250 students whose WQs were not returned by their parents/guardians was obtained, considering a proportion of $31 \%$ positive replies to the question regarding the presence of sibilus in the preceding 12 months. Correction was considered a requirement if the values obtained differed by at least $10 \%$ (increased or decreased) in comparison with the initially obtained values. Because a statistically significant difference occurred between the groups, the corrected prevalence for each question was calculated in order to estimate the true prevalence in the total population $(n=5,040)$ that initially received the ISAAC WQ.

Analysis of the differences in proportions between both genders and in association with the allergic diseases were performed through a Chi square test, and 
when required by the Fisher Exact test, with calculation of Odds Ratios (OR) and $95 \%$ confidence intervals $(95 \% \mathrm{CI}) . p$ values $<0.05$ were considered statistically significant.

\section{RESULTS}

The prevalences of allergic asthma, rhinitis and atopic eczema and their corrected values in relation to gender, as

Table 1. Prevalence of asthma (\%) symptoms, according to gender, in 3,312 6-7 year-old students from the western districts of São Paulo City"

\begin{tabular}{|c|c|c|c|c|}
\hline QUESTION & $\operatorname{MASC}(\mathrm{n}=1,510)$ & $\operatorname{FEM}(\mathrm{n}=1,671)$ & TOTAL $(\mathrm{n}=3,181)$ & ODDS RATIOS OR $(95 \% \mathrm{CI})$ \\
\hline 1. Sibilus ever in child's life & $59.0 *(966)$ & $51.5(863)$ & $55.2(1829)$ & $1.3(1.2-1.6)$ \\
\hline 2. Sibilus in the last year & $33.7 *(552)$ & $28.7(481)$ & $31.2(1033)$ & $1.3(1.1-1.5)$ \\
\hline \multicolumn{5}{|l|}{ 3. Number of crises in the last year } \\
\hline $1-3$ crises & $24.8(407)$ & $22.1(370)$ & 23.5 (777) & $1.2(1.0-1.4)$ \\
\hline $4-12$ crises & $6.3 *(104)$ & $4.7(78)$ & $5.5(182)$ & $1.4(1.0-1.9)$ \\
\hline$>12$ crises & $1.3(22)$ & $0.9(15)$ & $1.1(37)$ & $1.5(0.8-2.9)$ \\
\hline None & $67.4(1104)$ & $72.3(1212)$ & $69.9(2316)$ & $0.8(0.7-0.9)$ \\
\hline \multicolumn{5}{|l|}{$\begin{array}{l}\text { 4. Sleep prejudiced due to sibilus } \\
\text { in the last year }\end{array}$} \\
\hline$<1$ night/week & $14.5 *(239)$ & $12.0(201)$ & $13.3(440)$ & $1.2(1.0-1.5)$ \\
\hline$\geq 1 \mathrm{night} /$ week & $11.3^{*}(185)$ & $8.7(146)$ & $10.0(331)$ & $1.3(1.1-1.7)$ \\
\hline Never & $74.0(1213)$ & $79.3(1328)$ & $76.7(2541)$ & $0.7(0.6-0.9)$ \\
\hline \multicolumn{5}{|l|}{ 5. Speech limitation due to sibilus in } \\
\hline 6. Asthma ever & $8.1 *(132)$ & $6.1(102)$ & $7.1(234)$ & $1.3(1.0-1.8)$ \\
\hline \multicolumn{5}{|l|}{ 7. Sibilus accompanying exercises } \\
\hline in the last year & $9.6^{*}(159)$ & $7.6(127)$ & $8.6(286)$ & $1.3(1.0-1.7)$ \\
\hline 8. Nocturnal dry cough in the last year & $39.7 *(650)$ & $36.2(606)$ & $37.9(1256)$ & $1.2(1.0-1.3)$ \\
\hline
\end{tabular}

\# The data represent the $\%$ of the total of each column; $* p<0.05$ for the male gender

Table 2. Prevalence of rhinitis (\%) symptoms, according to gender, in 3,312 6-7 year-old students from the western districts of São Paulo City"

\begin{tabular}{|c|c|c|c|c|}
\hline QUESTION & $\operatorname{MASC}(\mathrm{n}=1,510)$ & $\operatorname{FEM}(n=1,671)$ & TOTAL $(\mathrm{n}=3,181)$ & ODDS RATIOS OR $(95 \% \mathrm{CI})$ \\
\hline \multicolumn{5}{|l|}{ 1. Sneezing, runny or blocked nose } \\
\hline 2. Sneezing, runny or blocked nose & & & & \\
\hline without cold in the last year & $30.7 *(503)$ & $27.2(455)$ & $28.9(958)$ & $1.2(1.0-1.4)$ \\
\hline $\begin{array}{l}\text { 3. Nasal symptoms + itchy-watery } \\
\text { eyes in the last year }\end{array}$ & $15.4(252)$ & $14.9(249)$ & $15.1(501)$ & $1.0(0.9-1.3)$ \\
\hline \multicolumn{5}{|l|}{ 4. Months with symptoms } \\
\hline January & $11.8^{*}$ & 10.7 & 22.5 & $1.2(1.0-1.4)$ \\
\hline February & 11.9 & 11.0 & 22.9 & $1.1(1.0-1.3)$ \\
\hline March & $11.3 *$ & 10.0 & 21.3 & $1.2(1.0-1.4)$ \\
\hline April & 10.8 & 9.8 & 20.6 & $1.2(1.0-1.4)$ \\
\hline May & 9.8 & 9.4 & 19.2 & $1.1(0.9-1.3)$ \\
\hline June & 9.2 & 8.5 & 17.7 & $1.1(0.9-1.4)$ \\
\hline July & 9.8 & 9.3 & 19.1 & $1.1(0.9-1.3)$ \\
\hline August & 10.7 & 10.2 & 20.9 & $1.1(0.9-1.3)$ \\
\hline September & 12.9 & 12.0 & 24.9 & $1.1(1.0-1.3)$ \\
\hline October & $13.8^{*}$ & 12.6 & 26.4 & $1.2(1.0-1.4)$ \\
\hline November & $14.2 *$ & 12.7 & 26.9 & $1.2(1.0-1.4)$ \\
\hline December & $13.7 *$ & 12.4 & 26.1 & $1.2(1.0-1.4)$ \\
\hline \multicolumn{5}{|l|}{$\begin{array}{l}\text { 5. Activities prejudiced due to nasal } \\
\text { symptoms in the last year }\end{array}$} \\
\hline Slightly & $12.6(207)$ & $11.4(191)$ & $12.0(398)$ & $1.1(0.9-1.4)$ \\
\hline Moderately & $5.0(82)$ & $3.8(63)$ & $4.4(145)$ & $1.3(1.0-1.9)$ \\
\hline A lot & $4.0 *(65)$ & $2.6(43)$ & $3.2(108)$ & $1.6(1.1-2.3)$ \\
\hline Never & $78.3(1283)$ & $82.3(1378)$ & $80.3(2661)$ & $0.8(0.6-0.9)$ \\
\hline 6. Rhinitis ever in child's life & $23.6 *(386)$ & $19.1(320)$ & $21.3(706)$ & $1.3(1.1-1.5)$ \\
\hline
\end{tabular}

\# The data represent the $\%$ of the total of each column; * $p<0.05$ for the male gender 

Lima R G et al.

Table 3. Prevalence of eczema (\%) symptoms, according to gender, in 3,312 6-7 year-old students from the western districts of São Paulo City

\begin{tabular}{|c|c|c|c|c|}
\hline QUESTION & $\operatorname{MASC}(\mathrm{n}=1,637)$ & $\operatorname{FEM}(\mathrm{n}=1,675)$ & $\operatorname{TOTAL}(\mathrm{n}=3,312)$ & ODDS RATIOS OR $(95 \% \mathrm{CI})$ \\
\hline 1. Itchy rash ever in child's life & $17.6(289)$ & $19.1(319)$ & $18.3(608)$ & $0.9(0.8-1.1)$ \\
\hline 2. Itchy rash in the last year & $12.2(199)$ & $13.5(226)$ & $12.8(425)$ & $0.9(0.7-1.1)$ \\
\hline 3. Located in skin folds & $9.0(148)$ & $10.0(168)$ & $9.5(316)$ & $0.9(0.7-1.1)$ \\
\hline \multicolumn{5}{|l|}{ 4. Age at appearance of rash } \\
\hline Under 2 years old & $4.0(66)$ & $4.6(78)$ & $4.3(144)$ & $0.9(0.6-1.2)$ \\
\hline Between 2 and 4 years old & $5.3(86)$ & $6.0(102)$ & $5.6(188)$ & $0.8(0.6-1.1)$ \\
\hline 5 years old or more & $6.6(108)$ & $7.2(120)$ & $6.8(228)$ & $0.9(0.7-1.2)$ \\
\hline 5. Rash cleared completely in the last year & $11.2(184)$ & $12.4(208)$ & $11.9(392)$ & $0.9(0.7-1.1)$ \\
\hline \multicolumn{5}{|l|}{ 6. Awoken at night due to itchy rash } \\
\hline$<1 \mathrm{x} /$ week & $2.8(46)$ & $3.6(61)$ & $3.2(107)$ & $0.7(0.5-1.1)$ \\
\hline$>1 \mathrm{x} /$ week & $2.0(34)$ & $1.9(32)$ & $1.9(66)$ & $1.1(0.7-1.8)$ \\
\hline Never & $95.2(1557)$ & $94.5(1582)$ & $94.8(3139)$ & $1.1(0.8-1.5)$ \\
\hline 7. Eczema ever in child's life & $6.1(183)$ & $12.8(215)$ & $12.0(398)$ & $0.8(0.7-1.1)$ \\
\hline
\end{tabular}

* No significant differences occurred in the prevalences between genders in the parameters for Eczema evaluated by the questionnaire

Table 4. Comparison of the asthma, rhinits and eczema (\%) symptom prevalences found and corrected in 3,312 6-7 yearold students from the western districts of São Paulo City

\begin{tabular}{|c|c|c|}
\hline QUESTION & ASTHMA MODULE & CORRECTED PREVALENCE*(IC 95\%) $(\mathrm{n}=5,040)$ \\
\hline 1. Sibilus ever in child's life & 55.2 & $43.5(41.9-45.4)$ \\
\hline 2. Sibilus in the last year & 31.2 & $24.4(23.3-26.0)$ \\
\hline \multicolumn{3}{|l|}{ 3. More than 1 crisis in the last year } \\
\hline 1 to 3 crises & 23.4 & $18.3(17.3-19.4)$ \\
\hline 4 to 12 crises & 5.5 & $4.1(3.6-4.7)$ \\
\hline$>12$ crises & 1.1 & 0 \\
\hline \multicolumn{3}{|l|}{$\begin{array}{l}\text { 4. Sleep prejudiced due to sibilus } \\
\text { in the last year }\end{array}$} \\
\hline awoken $<1$ night/week & 13.2 & $10.4(9.5-11.2)$ \\
\hline awoken $\geq 1$ night/week & 10.0 & $7.0(6.4-7.8)$ \\
\hline \multicolumn{3}{|l|}{ 5. Speech limitation due to sibilus } \\
\hline in the last year & 8.4 & $9.2(8-10.7)$ \\
\hline 6. Asthma ever in child's life & 7.1 & $5.7(5-6.7)$ \\
\hline \multicolumn{3}{|l|}{ 7. Sibilus accompanying exercise } \\
\hline in the last year & 8.6 & $8.3(7.5-9.0)$ \\
\hline \multirow[t]{2}{*}{ 8. Nocturnal dry cough in the last year } & 37.9 & $25.3(24.1-26.5)$ \\
\hline & RHINITIS MODULE & \\
\hline 1. Sneezing, runny or blocked nose with & er in child's life 34.8 & $29.0(27.5-30.8)$ \\
\hline 2. Sneezing, runny or blocked nose with & the last year $\quad 28.9$ & $25.7(24.2-27.5)$ \\
\hline 3. Nasal symptoms + itchy-watery eyes $i$ & 15.1 & $11.3(10.5-12.2)$ \\
\hline \multirow[t]{2}{*}{ 6. Rhinitis ever in child's life } & 21.3 & $20.0(18.6-21.8)$ \\
\hline & ECZEMA MODULE & \\
\hline 1. Itchy rash ever in child's life & 18.3 & $12.7(12.3-13.6)$ \\
\hline 2. Itchy rash in the last year & 12.8 & $9.2(8.8-10.1)$ \\
\hline 3. Located in skin folds & 9.5 & $7.3(6.8-8.4)$ \\
\hline
\end{tabular}

The corrected results were obtained through a representative sample of students whose WQs were not returned and represent the positive response percentage for each question in the total sample of 5,040 students

well as the OR and $95 \% \mathrm{CI}$ are presented in Tables 1 to 4.

Statistically significant associations occurred between the symptoms of asthma and rhinitis $(\mathrm{OR}=3.3 ; 95 \% \mathrm{CI}=$ 2.8 to $3.9 ; p<0.001)$, asthma and eczema $(\mathrm{OR}=2.2 ; 95 \% \mathrm{CI}$ $=1.8$ to $2.8 ; p<0.001)$ and rhinitis and eczema $(\mathrm{OR}=2.8$; $95 \% \mathrm{CI}=2.3$ to $3.4 ; p<0.001)$, evaluated by the positive responses to question number two of each WQ module.
Rhinitis symptoms in the preceding year occurred in $46.6 \%$ of students who presented sibilus in the same period, while eczema symptoms in the preceding year occurred in $19.5 \%$ of students who presented sibilus during the period. Rhinitis symptoms in the preceding 12 months occurred in $49.4 \%$ of students who presented eczema in the same period.

The number of students whose parents/guardians re- 
Table 5. Comparison of the asthma, rhinits and eczema (\%) symptom prevalences between Phases I and III B of the ISAAC project, with and without correction, in São Paulo City in 1995 and 2002

\begin{tabular}{|c|c|c|c|}
\hline QUESTION & $\begin{array}{c}\text { PHASE I - } 1995 \\
\text { Central-southern districts }\end{array}$ & $\begin{array}{l}\text { PHASE III B - } 2002 \\
\text { Western districts } \\
\text { Values found }\end{array}$ & $\begin{array}{l}\text { PHASE III B - } 2002 \\
\text { Western districts } \\
\text { Corrected values }\end{array}$ \\
\hline & ASTHMA MODULE & & \\
\hline 1. Wheezing ever in child's life & 49.3 & 55.2 & $43.5(41.9-45.4)$ \\
\hline 2. Wheezing in the last year & 21.3 & 31.2 & $24.4(23.3-26.0)$ \\
\hline 3. More than 1 crisis in the last year & 79.3 & 69.9 & \\
\hline 1 to 3 crises & 16.5 & 23.4 & $18.3(17.3-19.4)$ \\
\hline 4 to 12 crises & 3.6 & 5.5 & $4.1(3.6-4.7)$ \\
\hline$>12$ crises & 0.5 & 1.1 & - \\
\hline \multicolumn{4}{|l|}{$\begin{array}{l}\text { 4. Sleep prejudiced due to wheezing } \\
\text { in the last year }\end{array}$} \\
\hline Never awoken & 87.1 & 76.7 & \\
\hline awoken $<1$ night/week & 9.2 & 13.2 & $10.4(9.5-11.2)$ \\
\hline awoken $\geq 1$ night/week & 3.7 & 10.0 & $7.0(6.4-7.8)$ \\
\hline \multicolumn{4}{|l|}{ 5. Speech limitation due to wheezing } \\
\hline in the last year & 2.3 & 8.4 & $9.2(8.0-10.7)$ \\
\hline 6. Asthma ever in child's life & 6.1 & 7.1 & $5.7(5.0-6.7)$ \\
\hline \multicolumn{4}{|l|}{ 7. Wheezing accompanying exercise } \\
\hline in the last year & 5.5 & 8.6 & $8.3(7.5-9.0)$ \\
\hline \multirow[t]{2}{*}{ 8. Nocturnal dry cough in the last year } & 34.2 & 37.9 & $25.3(24.1-26.5)$ \\
\hline & RHINITIS MODULE & & \\
\hline $\begin{array}{l}\text { 1. Sneezing, runny or blocked nose } \\
\text { without cold ever in child's life }\end{array}$ & 40.0 & 34.8 & $29.0(27.5-30.8)$ \\
\hline $\begin{array}{l}\text { 2. Sneezing, runny or blocked nose } \\
\text { without cold in the last year } \\
\text { 3. Nasal symptoms }+ \text { itchy-watery }\end{array}$ & 33.8 & 28.9 & $25.7(24.2-27.5)$ \\
\hline eyes in the last year & 13.0 & 15.1 & $11.3(10.5-12.2)$ \\
\hline 6. Rhinitis ever in child's life & 28.8 & 21.3 & $20.0(18.6-21.8)$ \\
\hline & ECZEMA MODULE & & \\
\hline 1. Itchy rash ever in child's life & 13.6 & 18.3 & $12.7(12.3-13.6)$ \\
\hline 2. Itchy rash in the last year & 10.6 & 12.8 & $9.2(8.8-10.1)$ \\
\hline 3. Located in skin folds & 7.5 & 9.5 & $7.3(6.8-8.4)$ \\
\hline
\end{tabular}

sponded negatively to the questions related to asthma, rhinitis and eczema prevalence in the preceding year was 1,662 $(50.2 \%)$; these students were considered nonallergic.

Table 5 presents a comparison between the data obtained by Solé et al. in the central-southern districts of São Paulo in 1995 and the current study data from the same age group.

\section{DISCUSSION}

Allergic diseases are much more frequent in infancy and have a large social and economic impact. These facts stimulated epidemiological investigations that could identify regional prevalences and risk factors involved and, therefore afford early interventions to attenuate these effects ${ }^{18,19}$. ISAAC standardized a questionnaire written specifically for children and adolescent allergic diseases, which permits both prevalence evaluation and epidemiological data comparison over time in a single location and among different populations ${ }^{13,14}$.

The percentage of returned questionnaires can interfere in the results found and in the present study $65.7 \%$ of the questionnaires were returned, a percentage similar to that observed in other Brazilian centers who investigated the same age group, such as: Curitiba $(58 \%)^{20}$, a state capital city in southern Brazil; São Paulo $(72 \%)^{21}$, southeastern region; and Cuiabá $(73,2 \%)^{22}$, a central-western state capital city.

The rate of returned questionnaires reflects the difficulties encountered in the execution of epidemiological studies in Brazil, principally among deprived populations, with high illiteracy rates and the consequent difficulties in understanding the importance of populational inquiries. Despite the fact that the return index obtained in this research is considered adequate by the ISAAC International Committee, calculation of the corrected values was important, because all the prevalence values diminished significantly after correction, confirming the initial suspicion that the majority of children whose parents/guardians did not return the questionnaire, did so because their children presented no allergic disease symptoms ${ }^{13,14}$.

Even after correction, the western districts of São 
Paulo City presented high sibilus prevalence in the 12 months preceding the research, slightly larger than what was found in the central-southern districts of the city. In relation to Brazil, the prevalence observed in the western districts was greater than the mean found in ISAAC phase I, second only to that found in Recife ${ }^{23}$, in the northeastern region of the country. In Latin America, positivity for question number two was greater than the world average, but lower than the values for São Paulo. One possible explanation for this phenomenon, voiced by Mallol et al. ${ }^{24}$, is that asthma is more prevalent in countries with low socioeconomic levels, suggesting that poverty is an asthma risk factor and not a protection factor. The existence of high prevalences in countries with high socioeconomic levels contradicts this possibility. One of the hypotheses that relates greater exposure to microorganisms with diminished atopic disease is denominated the hygiene hypothesis. Given the characteristics of the population studied in the present work, it would be expected that the prevalences for allergic diseases were much lower in this population, a fact that was not observed ${ }^{5,6}$.

The questions that quantify the number of sibilant crises in the preceding year and the impairment of sleep due to sibilus, serve to identify individuals with persistent asthma symptoms, although these could also be related to signs of severity ${ }^{13}$. The data provided by these questions showed that the majority of students presented light to moderate disease symptoms.

The question that specifically evaluates the severity of asthma is the one which asks about speech limitation due to sibilus in the preceding year, which in this study was high compared to the phase I world data and much higher than that observed in the central-southern districts of São Paulo ${ }^{25}$. It is possible that this fact is also related to the characteristics of the population studied, since the inquiry dealt with a population with greater difficulties in accessing specialized health services, and thus not referred for the prophylactic treatment adequate for asthma. The high concentration of pollutants in the western districts of the city, originating from diesel oil combustion, may well also be associated with greater asthma prevalence in this population. Studies published from ISAAC phase I demonstrated that pollution showed little correlation with locations of greater symptom prevalences, as observed in Germany and Chile, for example, but that it may have some influence as an aggravating factor of asthma ${ }^{26,27}$.

The question, "Has your child ever had asthma?" evaluates previous medical diagnosis of asthma. Its low positivity in the present study contrasts with the high posi- tive response frequency to the question regarding symptoms suffered in the preceding 12 months and could indicate a lack of knowledge regarding the term "asthma" by the population and nonuse of this term by health professionals treating this population ${ }^{21,25}$. For this reason, this question has been considered to show high specificity, but low sensitivity ${ }^{13}, 14$.

Significantly greater asthma prevalence occurred among the male gender, as observed in the majority of asthma prevalence studies in the 6 and 7 year-old age group. This difference was not significant only for question seven ${ }^{21,24}$, "In the past 12 months, has your child's chest sounded wheezy during or after exercise?"

In relation to rhinitis, considering the corrected values, nasal symptom prevalence was similar to that observed in national centers during ISAAC phase I, but lower than that observed in the central-southern districts of São Paulo ${ }^{28,29}$. Regarding this aspect, some authors reported greater rhinitis prevalence in children from higher socioeconomic levels, which could facilitate the comprehension of the questions and produce more adequate replies ${ }^{29,} 30$.

The association of rhinitis with conjunctivitis symptoms indicates a diagnosis of rhinoconjunctivitis, which is more specific for the presence of atopy among individuals with nasal symptoms. The value found in this study was also less than that found in São Paulo phase I, but compatible with that observed in other Brazilian centers and with world data ${ }^{31}$.

A lower percentage of affirmative responses was obtained in relation to the presence of "rhinitis ever", when compared to that of question number two. Despite the fact that this difference was less than that observed with asthma, it might indicate lack of knowledge regarding the term "rhinitis" or lack of medical diagnosis, whether due to population inaccessibility to health services or due to unfamiliarity with, or even disregard of, rhinitis symptoms by medical professionals attending this population.

The months in which the students reported the greatest occurrences of nasal symptoms comprised the period from September to December, which is different from the period of greatest occurrence of viral infections in São Paulo, usually from May to August. This fact reinforces the diagnosis of allergic rhinitis in this study. However, this finding contrasts with that found in ISAAC phase I, where centers located in the southern and southeastern region, ns of Brazil presented greater nasal symptom prevalences in the coldest months of the year, from May to August, while in Brazilian centers of the northeastern region, where there are no cold/hot month con- 
trasts, no significant differences occurred over the months of the year ${ }^{28}$.

When the severity and prevalence of nasal symptoms was evaluated, the male gender was significantly more frequent, similar to that observed in asthma prevalence, and in agreement with data from around the world ${ }^{32}$.

In relation to eczema, data from the western districts of São Paulo were initially greater than those found in the central-southern districts for the first three questions; however, after correction, lower values for these questions were observed. Even so, the values found in this study could be considered high in relation to those observed in the rest of the world ${ }^{33}$. One possible explanation for this high prevalence is the profile of the evaluated casuistry. Because this is a disadvantaged population, living in worse hygienic and nutritional conditions, it is likely that a greater incidence of other pruriginous skin pathologies could be confused with the atopic eczema data, such as scabies, strophulus, urticaria, fungal infections and impetigo. One finding that reinforces this hypothesis is the fact that in the question regarding the period of the onset of symptoms, the majority of the students' parents or guardians affirmed that this occurred from the age of two years, differently from the majority of cases, where atopic eczema begins prior to this age ${ }^{34}$.

Indeed, despite the fact that the eczema module of the WQ was validated and is considered efficient for the detection of the prevalence of this disease, even the ISAAC International Committee recognizes that in the distinct realities of countries like India and Nigeria, where other pruriginous dermatosis, such as scabies, are much more frequent among children, a higher prevalence of "eczema" symptoms might occur ${ }^{33}$. This observation does not invalidate the data obtained using the ISAAC methodology, but must be considered when analyzing world data.

Medical diagnosis of eczema presented a slightly lower percentage than the prevalence shown in the preceding 12 months and, despite the fact that this was not evaluated through corrected values, it was very similar to that observed on the two occasions in which the ISAAC WQ was applied in the central-southern districts of São Paulo ${ }^{25}$.

Compared to the remaining national data from phase I, the diagnostic index of atopic eczema in the western districts of São Paulo could be considered low, since on that occasion, this index varied from $12.4 \%$ in Recife to $17.7 \%$ in Porto Alegre ${ }^{35}$, in the northeastern and southern regions of Brazil, respectively.

In this study, no significant differences were observed between genders regarding the prevalence and severity of eczema, but the majority of studies show a predominant manifestation in the female gender ${ }^{32}$. In São Paulo in 1996 and 1999, this predominance was slight, similar to that observed in the world data from the ISAAC phase I, when a female:male ratio of 1.3:1 occurred. This ratio was greater in countries with a greater prevalence of eczema symptoms $\mathrm{s}^{33}$.

In the present study, statistically significant associations were observed between the symptoms of asthma, rhinitis and eczema.

Asthma and rhinitis have been considered manifestations of the same inflammatory disease which impinges upon the air tracts, due to their epidemiological, anatomic and therapeutic similarities. This concept influences the current treatment tendencies, since it is known that adequate control of rhinitis can diminish inflammation of the lower air tracts and, therefore, contribute to the control of asthma $^{36}$.

The presence of rhinitis symptoms in $46.6 \%$ of students who presented sibilus in the preceding year was lower than that described by other authors, but similar to that observed in other Brazilian state capitals in the same age group, including in the central-southern districts of São Paulo ${ }^{37}$. One hypothesis that should be stated regarding this aspect is that some students who were identified by the presence of nasal and eczematous symptoms could present sibilus later on in life. Some authors have suggested a strong association between the personal history of rhinitis or eczema with the delayed onset of persistent asthma. This fact could be explained by the development of nonspecific bronchial hyperreactivity, since it is known that patients with rhinitis and asthma present greater hyperreactivity to methacholine, when compared to patients that present asthma alone ${ }^{25}$.

Association between all three diseases occurred in 3.8\% of the total number of students included in the study, which represents $12.2 \%$ for the same association in the asthmatics subgroup. This was similar to that observed by Solé et al. ${ }^{37}$ in the evaluation of the data collected in 1999. The association between asthma, rhinitis and eczema reiterates the hypothesis that these allergic diseases could be a single disease, presenting varied phenotypes according to age and compatible with the evolution of the atopic progress, according to which the clinical signs of eczema precede the development of asthma and rhinitis. Thus, eczema would be the "starting point" for the subsequent allergic diseases $^{34,38}$.

Standardized written questionnaires, such as the ISAAC, used in epidemiological studies can be considered valid methods for understanding prevalence variations, even though they are subject to criticisms regarding their applicability.

In this study, variable prevalence for atopic diseases was found in relation to other regions of the country and 
even in the western and central-southern districts of the city of São Paulo, demonstrating the need for regionalized epidemiological studies, especially in large metropolises. The data obtained in these epidemiological studies could aid in the elaboration of specific health planning for each region, aiding in the control of atopic diseases.

\section{RESUMO}

Lima RG, Pastorino AC, Casagrande RRD, Sole D, Leone C, Jacob CMA. Prevalência das doenças alérgicas em crianças de 6 a 7 anos na região oeste da cidade de São Paulo. Clinics. 2007;62(3):225-34.

OBJETIVOS: Avaliar a prevalência das doenças alérgicas na região oeste de São Paulo entre escolares de 6 a 7 anos e comparar os dados obtidos com aqueles da fase I da região centro-sul, através do questionário padronizado do International Study of Asthma and Allergies in Childhood.

MÉTODOS: Foram enviados 5040 questionários escritos com resposta de 3.312 alunos. As diferenças entre proporções foram avaliadas pelo Teste do Qui-quadrado ou Teste Exato de Fisher, se calculado a Razão das Chances, intervalo de confiança 95\% 
entre os sexos e doenças alérgicas. Os valores de $p<0,05$ foram considerados como significantes.

RESULTADOS: As prevalências corrigidas encontradas foram: asma $24,4 \%$, diagnóstico médico de asma $5,7 \%$, rinite $25,7 \%$, rinoconjuntivite $11,3 \%$, diagnóstico médico de rinite $20 \%$, eczema atópico 9,2\%. Houve associação significativa entre asma e rinite $(O R=3,3)$, asma e eczema $(O R=2,2)$ e rinite e eczema atópico $(\mathrm{OR}=2,8)$. $\mathrm{O}$ sexo masculino foi predominante para asma e rinite. Comparando-se os dados da fase I, observou-se prevalência mais elevada dos sintomas e gravidade de asma e valores menores para rinite e eczema.
CONCLUSÕES: As prevalências de asma e rinite neste estudo mostraram valores elevados em comparação ao diagnóstico médico. Houve predomínio do sexo masculino para asma e rinite. As associações mais freqüentes foram entre asma e rinite e asma e eczema. Em relação à região centro-sul de São Paulo, observou-se que na região oeste houve maior prevalência dos sintomas e gravidade da asma e menor prevalência de rinite e eczema.

UNITERMOS: Asma, Rinite, Eczema, Prevalência, Criança

\section{REFERENCES}

1. Magnus P, Jaakkola JJ. Secular trend in the occurrence of asthma among children and young adults: critical appraisal of repeated cross sectional surveys. BMJ. 1997;314:1795-9.

2. Aberg N, Hesselman B, Aberg B, Eriksson B. Increase of asthma, allergic rhinitis and eczema in Swedish schoolchildren between 1979 and 1991. Clin Exp Allergy. 1995;25:815-9.

3. Peat JK, van den Berg RH, Green WF, Mellis CM, Leeder SR, Woolcock AJ. Changing prevalence of asthma in Australian children. BMJ.1994;308:1591-6.

4. Von Mutius E, Fritzch C, Weiland SK, Roll G, Magnussen H. Prevalence of asthma and allergic disorders among children in united Germany: a descriptive comparison. BMJ. 1992;305:1395-9.

5. Varner AE. The increase in allergic respiratory diseases: survival of the fittest? Chest. 2002;121:1308-16.
6. Strachan DP. Hay fever, hygiene, and household size. BMJ. 1989;299:1259-60.

7. Samet JM. A historical and epidemiologic perspective on respiratory symptoms questionnaires. Am J Epidemiol. 1978;108:435-46.

8. Ferris BG. Recommended respiratory disease questionnaires for use with adults and children in epidemiological research. Am Rev Respir Dis. 1978;188:1-79.

9. Toren K, Brisman J, Jarvholm B. Asthma and asthma-like symptoms in adults assessed by questionnaires. A literature review. Chest. 1993;104:600-8

10. Solé D, Vanna AT, Yamada E, Rizzo MCV, Naspitz CK. International Study of Asthma and Allergies in Childhood (ISAAC) written questionnaire: validation of the asthma component among Brazilian children. J Invest Allergol Clin Immunol. 1998;8:376-82. 
11. Vanna AT, Yamada E, Arruda LK, Naspitz CK, Solé D. International Study of Asthma and Allergies in Childhood: Validation of the rhinitis symptom questionnaire and prevalence of rhinitis in schoolchildren in São Paulo, Brazil. Pediatr Allergy Immunol. 2001;12:95-101.

12. Yamada E, Vanna AT, Naspitz CK, Solé D. International Study of Asthma and Allergies in Childhood: Validation of the Written Questionnaire (eczema component) and prevalence of Atopic Eczema among Brazilian children. J Invest Allergol Clin Immunol. 2002;12:34-41.

13. International Study of Asthma and Allergies in Childhood - ISAAC Phase One Manual. Auckland (NZ)/Münster (FRG). October 1992. 47p.

14. Asher MI, Keil U, Anderson HR, Beasley R, Crane J, Martinez F, et al. The International Study of Asthma and Allergies in Childhood (ISAAC): Rationale and methods. Eur Respir J. 1995; 8:483-91.

15. Instituto Brasileiro de Geografia e Estatística. Anuário estatísitico do Brasil. Rio de Janeiro: IBGE; 2000.

16. CETESB, São Paulo: Relatório de qualidade do ar no Estado de São Paulo. São Paulo: CETESB; 1996. 78p. (Série Relatórios/CETESB).

17. Tarifa JR, Armani G. Atlas ambiental do Município de São Paulo. SVMA/ PMSP, Secr. de Planejamento - SEMPLA/PMSP. 2000; 86p.

18. Weiss KB, Sullivan SD. The health economics of asthma and rhinitis. Assessing the economic impact. J Allergy Clin Immunol. 2001;107:3-8.

19. Lodha R, Puranik M, Kattal N, Kabra SK. Social and economic impact of childhood asthma. Indian Pediatr. 2003;40:874-9.

20. Ferrari FP, Rosário, NA, Ribas LFO, Callefe LG. Prevalência de asma em escolares de Curitiba - projeto ISAAC. J Pediatr. 1998;74:299-305.

21. Solé D, Yamada E, Vana AT, Costa-Carvalho BT, Naspitz CK. Prevalence of Asthma and Related Symptoms in School-Age Children in São Paulo, Brazil - International Study of Asthma and Allergies in Childhood. $J$ Asthma. 1999;36:205-12.

22. Amorim AJ, Daneluzzi JC. Prevalence of asthma in school-age children. J Pediatr. 2001;77:197-202.

23. Solé D, Yamada E, Vana AT, Werneck G, Solano de Freitas L, Sologuren MJ, et al. International Study of Asthma and Allergies in Childhood (ISAAC): prevalence of asthma and asthma-related symptoms among brazilian schoolchildren. J Invest Allergol Clin Immunol. 2001;11:123-8.

24. Mallol J, Solé D, Asher I, Clayton T, Stein R, Soto-Quiroz M on behalf of the Latin American ISAAC Collaborators Group. Prevalence of Asthma Symptoms in Latin America: the International Study of Asthma and Allergies in Childhood (ISAAC). Pediatr Pulmonol. 2000;30:439-44.

25. Camelo-Nunes IC, Wandalsen GF, Melo KC, Naspitz CK, Sole D. Prevalência de asma e de sintomas relacionados entre escolares de São Paulo, Brasil: 1996 a 1999 - Estudo da reatividade brônquica entre adolescentes asmáticos e não asmáticos - "International Study of Asthma and Allergies in Childhood (ISAAC)". Rev Bras Alergia Imunopatol. 2001;24:77-89.
26. Wandalsen GF. Prevalência e fatores de risco para asma e doenças alérgicas em escolares da região centro-sul do município de São Paulo. [dissertação]. São Paulo: Universidade Federal de São Paulo, Escola Paulista de Medicina; 2003.

27. Davies RJ, Rusznak C, Devalia JL. Why is allergy increasing? Environmental factors. Clin Exp Allergy. 1998;28:S8-14.

28. The International Study of Asthma and Allergies in Childhood (ISAAC) Steering Committee. Worldwide variation in prevalence of symptoms of asthma, allergic rhinoconjunctivitis, and atopic eczema. Lancet. 1998;351:1225-32.

29. Solé D, Camelo-Nunes IC, Vana AT, Yamada E, Werneck F, Solano de Freitas L, et al. Prevalence of rhinitis and related-symptoms in schoolchildren from different cities in Brazil. Allergol Immunopathol (Madr). 2004;32:7-12.

30. Borges WG, Burns DAR, Felizola MLBM, Oliveira BA, Hamu CJ, Freitas VC. Prevalence of allergic rhinitis among adolescents from Distrito Federal, Brazil: comparison between ISAAC phases I e III. $J$ Pediatr. 2006;82:137-43.

31. Strachan D, Sibbald B, Weinland S, Ait-Khaled N, Anabwani G, Anderson HR, et al. Worldwide variations in prevalence of symptoms of allergic rhinoconjunctivitis in children: The International Study of Asthma and Allergies in Childhood (ISAAC). Pediatr Allergy Immunol. 1997;8:161-76.

32. Wieringa MH, Weyler JJ. Van Bever HP, Nelen VJ, Vermeire PA. Gender differences in respiratory, nasal and skin symptoms: 6-7 versus 13-14year-old children. Acta Paediatr. 1999;88:147-9.

33. Williams H, Robertson C, Stewart A, Ait-Khaled N, Anabwani G, Anderson R, et al. Wordwide variations in the prevalence of symptoms of atopic eczema in the International Study of Asthma and Allergies in Childhood. Allergy Clin Immunol. 1999;103:125-38.

34. Spergel JM, Paller AS. Atopic dermatitis and the atopic march. J Allergy Clin Immunol. 2003;112:S118-27.

35. Camelo-Nunes IC, Wandalsen GF, Melo KC, Naspitz CK, Solé D. Prevalence of atopic eczema and associated symptoms in schoolchildren. J Pediatr. 2004;80:60-4.

36. Bousquet J, Van Cauwenberge P, Khaltaev N. J. Aria Workshop Group World Health Organization. Allergic Rhinitis and its Impact on Asthma. Allergy Clin Immunol. 2001;108:5147-334.

37. Solé D, Camelo-Nunes IC, Wandalsen GF, Melo KC, Naspitz CK. Is rhinitis alone or associated with atopic eczema a risk factor for severe asthma in children? Pediatr Allergy Immunol. 2005;16:121-5.

38. Leung DY. Atopic dermatitis: New insights and opportunities for therapeutic intervention. J Allergy Clin Immunol. 2000;105:860-70. 